\title{
PENINGKATAN PRODUKTIVITAS KARYAWAN MELALUI PEMBERIAN INSENTIF
}

\author{
Oleh: Saliman \\ salimanjaper@uny.ac.id
}

\section{Abstrak}

Pihak manajemen selaku pimpinan pada suatu organisasi harus mampu menggerakkan bawahannya dalam rangka mencapai tujuan yang telah ditetapkan. Semangat kerja bawahan lambat laun akan mengalami erosi, maka manajer harus mampu menumbuhkan kembali gairah kerja bawahan, karena dapat menganggu jalannya organisasi atau perusahaan.Produktivitas karyawan adalah suatu kemampuan karyawan dalam menghasilkan produk (output), di perusahaan tempat karyawan bekerja. Produktivitas ini dipengaruhi oleh banyak hal yang salah satunya adalah upah atau khususnya insentif. Insentif adalah salah satu bentuk motivasi positif yang dinyatakan dalam satuan moneter. Insentif ini dimaksudkan untuk memberikan upah/gaji yang berbeda karena memang prestasi kerja yang berbeda. Di dalam suatu perusahaan produktivitas karyawan sangat penting. Sehingga harus senantiasa diusahakan dalam rangka optimalisasi dan efisiensi. Optimalisasi ini akan mendukung ekistensi penusahaan sebagai suatu organisasi yang mengacu kepada orientasi laba dan kesimbungan usahanya. Suatu perusahaan pastilah akan berupaya semaksimal mungkin untuk meningkatkan produktivitas karyawan, agar perusahaannya establish.

\section{Pendahuluan}

Manajer adalah orang yang bekerja dengan bantuan orang lain. Manajer tidak mungkin menyelesaikan seiuruh pekerjaannya seorang diri, akan tetapi akan meminta bantuan orang lain untuk melaksanakan sebagian pekejaannya, sehingga manajer harus mampu memberikan sebagian tugasnya kepada ba- wahannya yang dipandang mampu untuk melakukannya.

Organisasi merupakan alat sosial dan teknologis yang terialu luas dan kompleks, untuk dilaksanakan tanpa bekerjasama. Organisasi dapat dipandang sebagai suatu unit yang mengubah berbagai input menjadi output yang dibutuhkan masyarakat baik yang berupa barang 
maupun jasa. Pada akhirnya masyarakat memerlukan berbagai jenis organisasi dalam rangka memenuhi kebutuhan hidupnya. Masyarakat bukan hanya mengkonsumsi produk yang dihasilkan oleh organisasiorganisasi tersebut, akan tetapi lebih dari itu masyarakat juga merupakan bagian dari organisasi yang melakukan proses produksi dan input menjadi output. Bahkan masyarakat dalam hal ini sumber daya manusia merupakan komponen utama dalam organisasi.

Sumber daya manusia dalam suatu organisasi harus selalu dijaga dan dipelihara keberadaanya, agar mampu memberikan dukungan sepenuhnya terhadap organisasi dalam mencapai tujuan secara efektif dan efisien. Salah satu upaya memperhatikan keberadaan sumber daya manusia adalah dengan mempeThatikan nasibnya yang terkait dengan pemberian upah atau gaji yang layak dan memenuhi standar minimal kehidupannya.

Masalah gaji menjadi aspek yang paling urgen dalam hal pengelolaan sumber daya manusia, karena hampir seluruh manusia yang melakukan aktivitas di berbagai organisasi adalah dalam rangka memperoleh penghasilan untuk memenuhi tuntutan kehutuhan hidupnya. Dengan demikian masalah penggajian merupakan masalah yang cukup peka, kompleks dan rumit. Banyak sekali pengalaman empirik yang me- nunjukkan bahwa karyawan melakukan perlawanan terhadap pihak manajemen, hanya karena imbalan yang diperoleh dirasakan tidak sebanding dengan pengorbanan yang telah mereka sumbangkan kepada pihak manajemen. Sementara itu menurut kacamata para karyawan, pihak manajemen telah menikmati keuntungan yang berlebih dari hasil sumbangan kerja para karyawan. Perbedaan sudut pandang itulah yang sering menjadi pemicu benturan dalam tubuh organisasi. Pihak manajemen harus mampu mengeliminasi hal-hal seperti itu apabila mengharapkan organisasi yang dipimpinnya dapat tetap bertahan hidup.

Seorang karyawan mungkin telah menjalankan pekerjaan dengan baik, akan tetapi karyawan lain mungkin belum. Harapan pihak manajemen atau pimpinan adalah seluruh karyawan atau bawahan bekerja dan menjalankan tugasnya dengan baik, akan tetapi kalau tugas yang telah dibebankan kepada bawahan tidak terlaksana dengan baik, maka pihak pimpinan perlu mengatahui penyebab-penyebanya. Ada berbagai kemungkinan mengapa bawahan tidak bekerja dengan baik, dapat disebabkan bawahan memang tidak mampu mengerjakannya, dapat disebabkan fasilitasnya tidak mendukung, atau dapat disebabkan kurangnya motivasi dari bawahan untuk mengerjakan tugas- 
tugasnya. Apabila yang terjadi adalah kurangnya motivasi, maka menjadi tugas pimpinan untuk berperan memberikan motivasi kepada bawahan agar dapat bekerja sesuai dengan standar produksi yang telah ditetapkan.

Motivasi karyawan dalam bekaja sangatlah bervariasi antara satu karyawan dengan karyawan lain. Motivasi dalam bekarja menurut Widodo (Hani Handoko, 1994) adalah: a) mencari nafkah, b) mencari kekayaan, c) mencari kedudukan, dan d) mengembangkan ide atau Ideologi. Sedangkan menurut Djamaludin Ancok, yang menjadikan motivasi seseorang untuk bekerja adalah:

"a) kesempatan untuk maju dalam berkarier, b) rasa aman bahwa pekerjaan tersebut akan terus dimiliki c) atasan yang dapat memahami karyawan dan mempenakukan karyawan dengan adil, d) penghasilan yang memadai, e) teman bekerja yang kompak (saling percaya dan penuh pengertian), f) lingkungan fisik pekerjaan yang menyenangkan, g) pekerjaan yang intrinksik memang menyenangkan karena sesuai dengan bakat, minat, kemampuan dan aspirasi" (1985:5).

Keinginan untuk mempertahankan hidup merupakan salah satu sebab terkuat yang menyebabkan mengapa seseorang harus bekerja untuk mendapatkan penghasilan. Sementara itu kebutuhan-kebutuhan atau keinginan karyawan dalam bekerja tidak selalu sama atau konstan, namun umumnya mereka masih mempunyai keinginan yang hampir sama, seperti yang dikemukakan oleh Heidjrachman dan Suad Husnan sebagai berikut:

"Pada umumnya karyawan bekerja karena ingin mendapatkan: a) gaji dan upah yang baik, b) pekerjaan yang aman secara ekonomis, c) rekan kerja yang kompak, d) penghargaan terhadap pekerjaan yang dijalankan, e) pekerjaan yang berarti, f) kesempatan untuk maju, g) kondisi kerja yang aman, nyaman dan menarik, h) pimpinan yang adil dan bijaksana, i) pengarahan dan perintah yang wajar, j) organisasi atau tempat kerja yang dihartai masyarakat" (1984:183-184).

Dari berbagai pendapat di atas maka dapat disimpulkan bahwa secara umum orang bekerja baik secara mandiri maupun bekerja pada orang lain, tidak lain adalah dalam rangka meinperoleh penghasilan yang dapat digunakan untuk menutup kebutuhan-kebutuhan hidup diri dan keluarganya. Dengan demikian permasalahan ini tidak boleh dianggap sepele oleh pimpinan atau pihak manajemen dalam memenuhi hak-hak bawahannya, bahkan jika perlu bawahan diberikan jenis pendapatan ekstra yang sifatnya dapat memotivasi bawahan untuk lebih giat bekerja. 


\section{Produktivitas Karyawan}

Bagi perusahaan masalah produkivitas karyawan adalah merupakan suatu keharusan yang senantiasa selalu diusahakan dalam rangka optimalisasi dan efisiensi. Optimalisasi ini akan mendukung eksistensi perusahaan sebagai suatu organisasi yang mengacu pada orientasi laba dan kesinambungan usahanya. Kalau dikaitkan dengan penjelasan di atas, maka dapat ditarik benang merah bahwa upah dan gaji menjadi tujuan utama mengapa seorang bawahan bekerja. Maka menjadi kewajiban mutlak bagi pihak manajemen untuk memperhatikan upah dan gaji yang memadai bagi setiap bawahannya.

Upah atau gaji sebenamya merupakan imbalan atas prestasi karyawan. Semakin tinggi prestasi karyawan seharusnya semakin besar pula upah yang akan diterima. Prestasi ini biasanya dinyatakan sebagai produktivitas. Permasalahannya adalah sampai sekarang belum ada kesepakatan yang dapat dijadikan ukuran standar secara umum dalam menghitung produktivitas. Produktivitas merupakan masalah yang hangat dibicarakan akhir-akhir ini, karena produktivitas penting peranannya di dalam pencapaian tujuan organisasi. Produktivitas sebenamya telah ada sejak lama dan kini konsep tentang produktivitas mulai berkembang pesat.

Konsep tentang produktivitas ini mencakup pemgertian baik pro- duktivitas di tingkat makro maupun di tingkat mikro. Dalam hal ini Ravianto mengatakan bahwa: "Konsep produktivitas di tingkat makro mempunyai tujuan yaitu pembangunan ekonomi serta kesejahteraan masyarakat. Sedang konsep produktivitas di tingkat mikro mencakup: 1) produktivitas tenaga kerja, 2) produktivitas modal, 3) produktivitas produksi, 4) produktivitas organisasi, 5) produktivitas penjualan, dan 6) produktivitas produk. Pada akhirnya tujuan produktivitas di tingkat mikro adalah menghasilkan result yang berupa perkembangan (growth) melalui kemampuan menghasilkan laba perusahaan (profit ability) ${ }^{n}$ (1985: $16)$.

Usaha peningkatan produktivitas terutama produktivitas tenaga kerja sangat perlu dilakukan, karena produktivitas yang tinggi dari tenaga kerja tidak dapat dicapai begitu saja. Oleh karena itu perlu dicarikan terobosan untuk memacu produktivitas tenaga kerja dengan pemberian upah di luar gaji tetap yanga lazim disebut dengan insentif. Dengan insentif diharapkan dapat meningkatkan produktivitas karyawan, yang pada gilirannya dapat mendukung proses kelangsungan hidup organisasi.

\section{Insentif}

Insentif merupakan salah satu bentuk upah yang didiberikan oleh pihak manajemen kepada karyawan. Upah sebenarnya merupakan salah satu syarat perjanjian 
kerja yang diatur oleh pengusaha dan buruh atau karyawan serta pemerintah. Menurut Undang-undang Kecelakaan Tahun 1977 Nomor 33 pasal 7 ayat a dan b menjelaskan bahwa pengertian upah adalah sebagai berikut: a) tiap-tiap pembayaran berupa uang yang diterima oleh buruh sebagai ganti pekerjaan, b) perumahan, makanan, bahan makanan dan pakaian dengan percuma, yang nilainya ditaksir menurut harga umum di tempat itu. Sedang menurut Flipppo seperti dikutip Heidjrachman (1983:21), upah adalah harga untuk balas jasa yang diberikan oleh seseorang kepada orang lain. Ini berarti upah adalah hadiah kerja yang diberikan dalam bentuk finansial.

Struktur ekonomi dewasa ini adalah sedemikian rupa, sehingga mendorong orang untuk berproduksi guna mendapatkan uang, dan uang ini kemudian dapat ditukarkan sesuatu untuk memenuhi kebutuhan riil. Dengan demikian kerja dan upah serta upah dan kerja merupakan dua hal yang tidak dapat dipisahkan. Dalam bentukbentuk usaha pada umumnya yang dimaksudkan dengan upah adalah pengganti jasa bagi tenaga-tenaga kerja yang melaksanakan tugastugas dalam perusahaan yang sifatnya, produksinya, cara mengerjakannya dan sebagainya mudah sekali terpengaruh oleh faktor-faktor lain.
Inser.tif adalah upah yang diberikan kepada karyawan di luar gaji tetap, karena karyawan tersebut telah menunjukkan prestasi kerja di atas rata-rata. Upah tersebut ditetapkan sebagai upaya untuk memotivasi agar karyawan dapat lebih meningkatkan produktivitasnya. Dengan penetapan insentif tersebut harapannya karyawan akan berusaha bekerja semaksimal mungkin untuk dapat meraihnya, karena hanya dengan hasil kerja di atas standar karyawan baru dapat memperoleh insentif.

Seperti telah dijelaskan di atas insentif dimaksudkan untuk memberikan upah atau gaji yang berbeda karena prestasi kerja yang berbeda. Sistem insentif dapat memotivasi para karyawan supaya lebih banyak berproduksi, yang pada akhimya akan lebih banyak menerima penghasilan. Di depan telah dijelaskan bahwa salah satu penyebab mengapa karyawan tidak dapat berprestasi atau tidak dapat menyelesaikan pekerjaannya dengan baik, adalah karena kurangnya motivasi. Salah satu bentuk motivasi yang dapat diberikan oleh pihak manajemen adalah dengan memberikan penghargaan yang berujud uang. Pelaksanaan sistem insentif ini dilakukan oleh perusahaan dalam rangka meningkatkan produktivitas karyawan, dan di sisi lain dalam rangka mempertahankan karyawan yang 
berprestasi untuk tetap setia pada perusahaan.

\section{Pemberian insentif adalah su-} atu bentuk motivasi yang dinyatakan dalam satuan moneter, jadi termasuk jenis motivasi positif. Kehernasilan motivasi pada suatu perusahaan dapat diukur dari output (produk) yang dihasilkan perusahaan itu sendin. Insentif adalah pemberian upah/gaji yang berbeda karena memang prestasi kerja yang berbeda. Jadi dua karyawan yang mempunyai jabatan yang sama dapat menerima upah yang berbeda karena prestasi yang berbeda. Gajilupah dasar bagi mereka memang sama, tetapi karena prestasi yang berbeda, misalnya yang satu bekerja di atas standar produksi, maka ia akan menerima tambahan bonus. Pelaksanaan sistem insentif ini dimaksudkan pensahaan terutama untuk meningkatkan produktivitas karyawan, dan mempertahankan karyawan yang berprestasi untuk tetap berada dalam perusahaan.

Pada suatu perusahaan insentif lazimnya diberikan kepada karyawan bagian produksi (blue collar workers) yang meliputi tenaga pimpinan (executive persona), karyawan penjualan (salesman) dan sebagainya. Insentif ini menurut Hejirachman (1984:153) mempunyai beberapa sifat dasar, antara lain: 1) Pembayarannya hendaknya sederhana sehingga dapat dime- ngerti dan dihitung oleh karyawan sendiri, 2) Penghasilan yang diterima buruh hendaknya menaikkan uotput dan efisiensi, 3) Pembayarannya hendaknya dilakukan secepatnya, 4) Standar kerja hendaknya ditentukan dengan hati-hati, standar kerja yang terialu tinggi dan terlalu rendah sama tidak baiknya, 5) Besarnya upah normal dan standar kerja perjam hendaknya cukup merangsang pekerja untuk bekerja lebih giat.

Secara sederhana pelaksanaan sistem insentif ini dapat digambarkan berikut ini: Karyawan bagian produksi di sebuah perusahaan mempunyai tugas yang sangat penting. Hasil produksi perusahaan ditentukan oleh kemampuan yang dimilikj karyawan produksi di samping faktor-faktor lain. Produktivitas karyawan bagian produksi sangat diharapkan. Salah satu cara meningkatkan produktivitas karyawan ini adalah dengan memberikan insentif. Jenis insentif untuk karyawan produksi terdiri dari 3 macam yaitu :

1. Insentif finansial (finansial incentif) yaitu insentif yang diberikan kepada karyawan produksi, yang meliputi bonus, bagian keuntungan dari perusahaan, kesejahteraan sosial seperti pemeliharan kesehatan, rekreasi dan lain-lain.

2. Insentif Non finansial (non financial intensif) yaitu sikap pimpinan 
yang dapat memberikan kepuasan kepada karyawan serta situasi kerja yang menyenangkan.

3. Insentif sosial (social incentif) yaitu sikap dan keadaan tingkah laku dari anggota-anggota organisasi terhadap pegawai yang bersangkutan.

Insentif untuk karyawan bagian produksi ada dua jenis yaitu: time bonuses dan insentif seluruh karyawan. Jadi karyawan produksi akan mendapat insentif yang berupa bonus berdasarkan waktu kerja, dan bonus yang diterima secara umum sebagai karyawan perusahaan, misalnya pemilikan saham perusahaan atau pembagian laba perusahaan. Secara rinci dapat dijelaskan sebagai berikut:

1. Time bonuses, menurut sistem ini bonus yang diberikan kepada karyawan produksi didasarkan waktu yang dihemat dan waktu pengerjaan, serta waktu standar.

2. Insentif untuk seluruh karyawan, kadang-kadang perusahaan di samping membuat berbagai sistem insentif untuk kelompokkelompok karyawan tertentu, juga membuat sistem insentif yang beriaku untuk seluruh karyawan, misalnya pemilikan saham bersama dan pembagian laba.

Dari berbagai sistem insentif tersebut dapat dilihat bahwa besarnya upah yang akan diterima oleh masing-masing karyawan akan berbeda-beda. Yang penting di sini adalah bahwa sistem manapun yang dipilih, hendaknya sistem tersebut mampu memenuhi tujuan yang telah ditetapkan, yaitu meningkatkan output dan efisiensi, hal lain yang tidak boleh dilupakan adalah bahwa hendaknya sistem yang dipilih itu cukup sederhana, sehingga dapat dimengerti oleh para karyawan.

Uraian di atas menjelaskan bahwa pemberian insentif merupakan salah satu upaya memotivasi karyawan supaya lebih giat bekerja, agar kelangsungan hidup perusahaan lebih terjamin, serta efisiensi dapat tercapai. Di samping itu melalui insentif tersebut juga dapat menseleksi karyawan yang berkualitas dan yang kurang berkualitas, sekaligus dapat mempertahankan karyawan yang berkualitas untuk tetap setia pada perusahaan. Agar karyawan dapat menghitung sendiri berapa insentif yang akan diperoleh dari prestasi kerjanya, maka rancangan sistem insentif harus dikomunikasikan kepada karyawan serta formulasi perhitungannya harus jelas.

\section{Pengaruh Insentif Terhadap Pro- duktivitas}

Produktivitas karyawan sebagai sutau konsep menunjukkan adanya keterkaitan antara hasil kerja (output) dengan satuan waktu. Se- 
orang karyawan yang produktif adalah karyawan yang cekatan dan mampu menghasilkan barang dan jasa sesuai mutu yang ditetapkan, dengan waktu yang lebih singkat. Karyawan yang produktif juga dapat dikatakan apabila mampu menghasilkan output atau produk yang lebih besar dari karyawan lain.

Produktivitas karyawan dimungkinkan dapat tercapai apabila karyawan telah mendapat pendidikan dan latihan yang memadai, sehat dan berenergi, peralatan yang lengkap dan adanya kesempatan berprestasi yang terbuka. Karyawan juga harus mempunyai sikap, etika dalam bekerja dan motivasi terhadap mutu kehidupan hari esok yang lebih baik. Harapan karyawan akan terwujud apabila karyawan mempunyai penghasilan lebih, sehingga dapat memenuhi kebutuhan-kebutuhan lainnya di luar kebutuhan fisiologis.

Untuk mengatakan apakah seorang karyawan produktif atau tidak, maka periu ada ukuran yang jelas mengenai konsep produktivitas. Ravianto (1985:20) secara tegas menjelaskan bahwa produktivitas secara lebih empirik dapat diukur dari perbandingan antara input dengan uotput. Dengan demikian produktivitas karyawan mengandung pengertian perbandingan antara hasil yang dicapai dengan peran serta karyawan per satuan waktu.
Harapan kehidupan hari esok yang lebih baik dari setiap karyawan, merupakan motivasi intrinsik yang dapat memacu karyawan untuk mencari penghasilan yang lebih besar, agar mempu menebus kebutuhan-kebutuhan hidupnya, mulai dari kebutuhan fisiologis sampai kebutuhan aktualisasi diri. Peluang ini harus dapat dimanfaatkan oleh pihak manajemen dengan baik, yaitu dengan memberikan kesempatan seluas-luasnya kepada karyawan untuk memperolah apa yang karyawan harapkan, yaitu penghasilan lebih besar. Caranya adalah dengan pemberian upah di luar gaji tetapnya yaitu insentif. Dalam hal ini hanya karyawan yang produktif saja yang berhak memperoleh insentif, yaitu karyawan yang mampu menghasilkan produk lebih banyak dari produk yang seharusnya dihasilkan, dengan standar waktu yang sama. Tentunya dengan tetap memperta. hankan kualitas. Dengan demikian maka jelaslah bahwa dengan pemberian insentif akan mampu memotivasi karyawan untuk meningkatkan produktivitasnya. Semakin besar insentif yang diberikan maka akan semakin tinggi pula motivasi karyawan untuk meningkatkan produktivitasnya.

Bagi seorang karyawan, nilai upah kadang-kadang bukan merupakan kebutuhan multak, namun untuk memenuhi kebutuhan fisiologis dan biologis dasar mereka 
menjadi mutlak adanya. Apabila kebutuhan dasar telah terpenuhi, nilai upah akan memberikan kesempatan untuk melengkapi kebutuhan ekonomi yang lain. Pertimbangan utama lainnya adalah dengan adanya perasaan puas terhadap upah yang diterima oleh karyawan, akan menimbulkan dampak positif terhadap peningkatan produktivitas kerjanya. Seperti yang dikatakan para ahli, bahwa suatu nilai upah kerja itu bagi setiap karyawan akan mempunyai suatu kekuatan yang berbeda dalam memacu produktivitas kerja karyawan.

\section{Plus Minus Insentif}

Ide dasar pemberian insentif sangat mulia yaitu untuk meningkatkan output dan efisiensi. Akan tetapi haruslah disadari bahwa berbagai kesulitan akan timbul dari sistem insentif tersebut. Kesulitan tersebut antara lain adalah:

1. Beberapa alat pengukur dari berbagai prestasi karyawan haruslah dapat dibuat secara tepat, alat pengukur ini haruslah dapat diterima dan wajar.

2. Berbagai alat pengukur ini haruslah dihubungkan dengan tujuan perusahaan yang akan ditetapkan.

3. Data yang menyangkut berbagai prestasi harusiah dikumpulkan tiap hari, minggu atau bulan.

4. Standar yang ditetapkan haruslah mempunyai kadar/tingkatan kesulitan yang sama untuk setiap kelompok kerja.

5. Gaji/upah total dan upah pokok ditambah bonus yang diterima, haruslah konsisten di antara berbagai kelompok pekerja yang menerima insentif, dan di antara kelompok pekerja yang meneri$\mathrm{ma}$ insentif dan tidak menerima insentif.

6. Standar prestasi haruslah disesuaikan secara periodik, dengan adanya perubahan dalam prosedur kerja.

7. Kemungkinan oposisi dari pihak serikat buruh sudah harus diperkirakan.

8. Berbagai reaksi karyawan terhadap sistem insentif yang kita lakukan juga sudah harus diperkirakan.

Dari berbagai kesulitan di atas jelaslah bahwa perusahaan harus berlaku ekstra hati-hati di dalam merancang sistem insentif.

\section{Kesimpulan}

Produktivitas karyawan adalah suatu kemampuan karyawan dalam menghasilkan produk (output), di perusahaan tempat karyawan bekerja. Produktivitas ini dipengaruhi oleh banyak hal yang salah satunya adalah upah atau khususnya insentif. Insentif adalah salah satu bentuk motivasi positif yang dinyatakan dalam satuan moneter. Insentif ini dimaksudkan untuk memberikan upah/gaji yang berbe- 
da karena memang prestasi kerja yang berbeda.

Di dalam suatu perusahaan procluktivitas karyawan sangat penting. Sehingga harus senantiasa diusahakan dalam rangka optimalisasi dan efisiensi. Optimalisasi ini akan mendukung eksistensi perusahaan sebagai suatu organisasi yang mengacu kepada orientasi laba dan kelangsungan hidup usahanya. Suatu perusahaan pastilah akan berupaya semaksimal mungkin untuk meningkatkan produktivitas karyawan, agar perusahaannya establish.

Insentis diberikan secara berbeda untuk masing-masing karyawan, walaupun mungkin mereka bekerja pada bagian yang sama. Pada dasamya gaji pokok mereka sama, tetapi karena prestasinya tidak sama maka upah yang mereka terima dapat saja menjadi berbeda. Karena insentif untuk masing-masing karyawan berbeda ditentukan sesuai dengan prestasinya. Hal ini tentu akan membuat mereka berusaha meningkatkan prestasinya. Pada dasamya karyawan akan merasa puas apabila prestasinya dihargai. Dengan prestasi karyawan yang meningkat berarti produktivitas juga meningkat dan tentunya laba perusahaan akan meningkat.

\section{Daftar Pustaka}

Hadi Poenwono. 1979. Tata Personalia (Personal Management). Cetakan ke Empat. Jakarta: Djernbatan.

Heidjrachman Ranupandojo dan Suad Husnan. 1984. Manajemen Personalia. Yogyakarta: BPFE-UGM

Miftah Thoha. 1997. Pembinaan Organiasai. Proses Diagnosa dan Intervensi. Jakarta: PT Raja Grafindo Persada.

-.-. 1998. Penilaku Organisasi, Konsep Dasar dan Aplikasinya. Jakarta: PT Raja Grafindo Persada.

Manullang, M. 1985. Pokok-Pokok Manajemen Personalia. Cetakan ke Empat. Jakarta: $\mathrm{CV}$ Ghalia Indonesia.

Hani Handoko, T. 1984. Manajemen Edisi I. Cetakan Pertama. Yogyakarta: BPFE-UGM Wahjosumidjo. 1994. Kepemimpinan dan Motivasi. Jakarta: Ghalia Indonesia.

\section{Biodata}

Drs. Saliman, lahir di Purbalingga, 3 Agustus 1966. Menyelesaikan S1 Pend. Administrasi Perkantoran tahun 1990 di IKIP Semarang. Mulai 1993 menjadi staf edukatif di Pend. Administrasi Perkantoran FPIPS IKIP Yogyakarta, yang sekarang dikenal FIS-UNY. Saat ini sedang menempuh S2 di PPS UNY. 